\title{
Code Alternations in Bilingual Representation and a Communication Strategy in Tuan Guru Bajang's Islamic Speech
}

\author{
Lalu Thohir \\ FKIP Universitas Mataram \\ mq.afif@gmail.com
}

\begin{abstract}
The present writing is a study of code alternation in $T G B$ 's Islamic speech. TGB which stands for "Tuan Guru Bajang" is a well-known name for Dr. M. Zainul Majdi, M.A, a famous Islamic preacher in Lombok and at present, he is the governor of West Nusa Tenggara province. The data of this study were obtained from one of $T G B$ 's Islamic speech recordings. They were first classified into inter-sentential switching, tag-switching, and intrasentential switching and then they were analyzed to know their functions which involve a topic switch, effective and repetitive functions. The findings show that intra-sentential switching which reflects repetitive function appeared most frequently in $T G B$ 's Islamic speech. The code alternation in $T G B$ 's Islamic speech represents bilingualism and has proved to be an effective strategy in communication.
\end{abstract}

\section{ARTICLE HISTORY}

Received 21 April 2017

Accepted 9 September 2017

\section{KEYWORDS}

Bilingual; code alternation; communication strategy

\section{Introduction}

This is the most common phenomenon that people who live in a bilingual or multilingual environment speak or use more than one language simultaneously and switch from one language to another. According to Wei (2008:4), when bilingual and multilingual speakers meet, an issue for consideration and negotiation is which language should be used. However, most bilingual and multilingual speakers seem to know which language is the most appropriate for a given situation, and when they need to switch from one language to another in the middle of a conversation.

The case of alternating or switching from one language to another is commonly known as 'code-switching.' However, the term code-switching is also used to address the alternating in different styles within the same language, for example, formal and informal speech between monolinguals. Thus, code-switching can take place in monolingualism when changing styles, but here it narrows down the scope of codeswitching.

Being able to communicate in two or more languages gives individuals opportunities to express their feelings and thoughts and to shape their identity. It also 
helps them satisfy their individual and social needs in the different contexts of the languages used(Muysken, 2000).

Tuan Guru (a term for Islamic preachers in Lombok island) usually used two languages - Indonesian and Sasak when they deliver Islamic speeches toa community or an Islamic congregation. Tuan Guru usually alternates the codes between those two languages when necessary to make their Islamic speeches more comprehensible.

The fact that Tuan GuruBajang (henceforth called TGB) usually uses two languages when delivering his Islamic speeches encouraged the writer to carry out a study of code alternation in his speech. $T G B$ is a well-known name given to Dr. Muhammad Zainul Majdi, M.A., one of the famous Islamic preachers in Lombok Island and since 2008 up to now (2017) he is a governor of West Nusa Tenggara.

Specifically, the writer was intended to answer the following questions: (1)Which type of code is switching among inter-, tag- or intra-code switching was more frequently used by $T G B$ when delivering Islamic speech? (2) What functions do these three types of code-switching in $T G B$ 's Islamic speech perform?

\section{Background Literature}

\section{Bilingual and Multilingual}

Simply, bilingual is defined as a person who uses at least two languages with some degree of proficiency, whereas, multilingual is defined as a person who knows and uses three or more languages. A bilingual or multilingual person usually has a better knowledge of one language than another(Richards and Schmidt, 2002:51).In other words, a bilingual or multilingual person does not know all the languages equally well.

In a similar view, Wardhaugh (2006:96) states that people who are bilingual or multilingual do not necessarily have the same abilities in the languages, in fact, that kind of parity may be exceptional. He, further, explains that the competence differences in the various languages might range from command of a few lexical items, formulaic expressions, and rudimentary conversational skills.

\section{Code Alternation}

The term 'code' can be used to refer to any kind of system that two or more people employ for communication (Wardhaugh, 2006:88). It also used to refer to any system of signals, numbers, words, which carries concrete meaning (Gumperz, 1982). In the context of sociolinguistics, code refers to a term used instead of language, speech variety, or dialect. It is used to stress the uses of a language or language variety in a particular community (Richards and Schmidt, 2002:79).

The term 'code alteration refers to the alternating use of two or more languages (Auer, 1995 cited in Kamwangamalu, 2010). In the study of code alternation, the 
distinction between 'code-switching' and 'code-mixing' is one of the most puzzling (Claros and Isharyanti, 2009). The term 'code-mixing' is sometimes defined or used separately from 'code-switching,' but it is common that the 'code-switching' is used as a cover term including code mixing as well. Anyhow, the term 'code alternation' can be used to refer to 'code-switching' and 'code mixing.'

\section{Code Switching}

Code-switching has been defined in some ways and also spelled differently by different researchers, such as code-switching, code-switching, and codeswitching. In this study, the spelling 'code-switching' is adopted. Code-switching is defined as a change by a speaker (or writer) from one language or language variety to another one(Richards and Schmidt, 2002:81).In other words, Cook (2008:174)defines codeswitching as a process of going from one language to the other in mid-speech when both speakers know the same languages.

In its most specific sense, code-switching, according to Meyerhoff (2006:116), is the alternation between varieties, or codes, across sentences or clause boundaries. Whereas Claros and Isharyanti (2009) state that code-switching is inter-sentential code-alternation which occurs when a bilingual speaker uses more than one language in single utterance above the clause level to appropriately convey his/her intents such as in the following excerpt.

Excerpt 1: Example of code-switching (English/Spanish)

A: The price looks so cool.

B: Which picture?

A: The one you have in your messenger.

B: Ah...Si, me gusto mucho. (Ah...yes, I liked it a lot)

\section{Code Mixing}

Code mixing is defined as the mixing of two codes or languages, usually without a change of topic. It can involve various levels of language,e.g., phonology, morphology, grammatical structures or lexical items (Richards and Schmidt, 2002:80).

According to Meyerhoff (2006:120), code mixing generally refers to the alternation between varieties, or codes, within a clause or phrase instead of across clauses. In this way, Claros and Isharyanti (2009) state that code-mixing is intra-sentential codealternation which occurs when speakers use two or more languages below clause level within one social situation.

Further, according to Muysken (2000), there are three types of code mixing: insertion, alternation and congruent lexicalization. The first, insertion, occurs when lexical items from one language are incorporated into another. The second, alternation, occurs when structures of two languages are alternated indistinctively 
both at the grammatical and lexical level. The last, congruent lexicalization, refers to the situation where two languages share grammatical structures which can be filled lexically with elements from either language.

To have clear understanding of those three types of code mixing, it is worth noting the following examples given by Claros and Isharyanti (2009).

Excerpt 2a: Example of insertion (Indonesian/English)

$\mathrm{B}$ : Tergantung team, terus juga tergantung event.

(It depends on the team and the event.)

Excerpt 2b: Example of alternation (English/Indonesian)

B: I mean, ganti ke kalimat laen.

(I mean, change it to another sentence.)

Excerpt 2c: Example of Congruent lexicalization (Indonesian/English)

B: Software gua buat convert file wav jadi mp3 gua uda expired.

(My software for converting wav files to mp3s has expired.)

\section{Types of Code Switching}

Considering the situation when code-switching occurs, code switching can be categorized into situational and metaphorical. Situational code-switching occurs when the languages used change according to the situations in which the speakers use one language in one situation and another in a different one and no topic change is involved. But when a change of topic requires a change in the language, this type of code-switching is categorized into metaphorical code-switching. As the term itself suggests, metaphorical code-switching has an affective dimension to it in which the speakers change the code as they redefine the situation - formal to informal, official to personal, serious to humorous, and politeness to solidarity (Wardhaugh, 2006:104).

In other words, situational code-switching is triggered by a change in the situation. Whereas, metaphorical code switching referred to changes in the speaker's language choice when the situation remained the same (Wei,1999:156). Further, situational code-switching, according to Meyerhoff (2006:116), is categorized into domainbased and addressee-based. The former is when code-switching is constrained by where speakers happen to be, and the latter is when code-switching is constrained by whom a speaker happens to be talking to.

From the perspective of the sentential construct, code-switching is categorized into intra-sentential switching, tag switching and inter-sentential switching(Poplack, 1980). The inter-sentential switching takes place between sentences, i.e., the switch occurs at a clause or sentence boundary where each clause or sentence is in a different language. Furthermore, inter-sentential switching may take place between 
turns. This type of switching requires the least integration as codeswitching happens between sentences. Below is an example of inter-sentential switching:

Sometimes I'll start a sentence in Spanish y terminó e n espanol. (Sometimes I'll start a sentence in Spanish and finish it in Spanish.)

The tag-switching, however, requires only little integration of the two languages. Romaine (1995:122) states that as the term itself suggests, tag-switching involves inserting a tag in one language to an utterance in another language.

According to Poplack (1980), the insertion of a tag to an utterance has virtually no ramifications for the rest of the sentence. This is because tags have no syntactic constraints, they can be moved freely, and they can be inserted almost anywhere in discourse without violating any grammatical rules, such as 'you know,' 'you mean' in: Se sininen talo, you know(that blue house, you know).

On the other hand, the intra-sentential code switching occurs within a sentence. As this is so, it also involves the greatest syntactic risk as words or phrases from another language are inserted into the first language within one sentence or utterance. As two languages are mixed within a sentence, there are also two different grammars in play which mean that the speaker has to know both grammars in order to produce a grammatically correct utterance. This is to say that the speaker needs to know the two grammars to avoid ungrammatical utterances. Poplack (1980) provides an example of intra-sentential switching between English and Spanish and a figure showing different types of code-switching as follows:

Why make Carol SENTARSE ATRAS PA'QUE everybody has to move PA'QUE SE SALGA? (Why make Carol sit in the back, so everybody has to move for her to get out?).

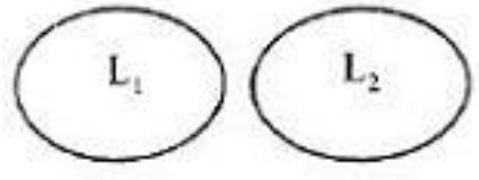

a. Inter-sentential switching

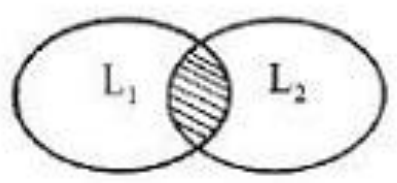

b. 'tag'-switching

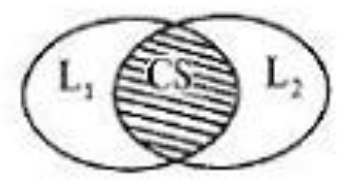

c. Intra-sentential switching

Figure 1. The types of code switching and the degree of code-switching in them

Inspecting Figure 1, we can see that in inter-sentential switching, there is no codeswitching within a sentence but the two different languages are in different sentences or clauses (the two circles represent the two sentences or clauses). In tag switching, there is a little switching within a sentence or a clause, but this code-switching is usually a tag. The circles in the figure demonstrate this as the two interlocked circles 
comprise one sentence or clause where in the middle there is little code-switching. Finally, in intra-sentential switching, the amount of code-switching is the greatest. It is considered that intra-sentential code switching to be a code mixing instead of a code-switching.

In this study, however, the term 'code-switching' covers the term 'code mixing,' and to determine the types of code switching in $T G B$ 's Islamic speech, the terms 'intra-sentential code switching,' 'inter-sentential code switching'and 'tag switching' are employed.

\section{The Functions of Code Switching}

People who speak more than one language or have command over more than one variety of any language are equally aware that in some contexts one variety will serve their needs better than another (Meyerhoff, 2006:115). In other words, bilingual or multilingual people change the variety they use, i.e., do code switching to serve their needs, and they switch the codes for various reasons, such as to assert power; declare solidarity; maintain a certain neutrality when both codes are used; express identity; and so on (Wardhough, 2006:110)

In the context of monologue, such as in delivering the speech, code switching serves some functions, and those functions might be associated with the functions of teachers' use of code switching mentioned by Mattson and Burenhult (1999:61). According to them, teachers' use of code switching serves some basic functions, and these functions are listed as the topic switch, affective, and repetitive functions.

In topic switch cases, the teacher alters his/her language according to the topic that is under discussion. In these cases, the students' attention is directed to the new knowledge by making use of code switching and accordingly making use of native tongue.

In addition to the function of code switching named as the topic switch, the phenomenon also carries affective functions that serve for expression of emotions. In this respect, code switching is used by the teacher in order to build solidarity and intimate relations with the students.

Another explanation for the functionality of code switching is its repetitive function. In this case, the teacher uses code switching in order to transfer the necessary knowledge for the students for clarity. Following the instruction in the target language, the teacher switches code to native language in order to clarify meaning, and this way stresses importance on the foreign language content for efficient comprehension.

\section{Research design}

This study is a qualitative one which is categorized into ethnomethodology. Ethnomethodology is one of the research traditions in qualitative research which 
aims at uncovering or analyzing meanings contained within conversation or text(Snape and Spencer,2003:12). The data for this study were obtained from the audio-recording of $T G B$ 'sIslamic speech for 36 minutes, and 32 seconds which was taken in December, $07^{\text {th }} 2007$

The audio-recording is an Islamic speech which took place in Al-Ihsan mosque in Suka village Lunyuk district in Sumbawa island West Nusa Tenggara, in which the inhabitants and the majority of the audience were from Lombok whose native language is Sasak language. This Islamic speech was delivered in a combination of Indonesian and Sasak in which the Indonesian language was the first or main language due to toa large number of utterances in this speech was delivered in Indonesian, whereas Sasak was the second or supplementary language as a small number of the utterances in this speech were delivered in Sasak language.

In order to get the data dealing with code alternation, the writer played the audio-recording several times and transcribed the tapes of utterances or sentences which contained code switching from Indenesian to Sasak and vice verse. To differentiate the codes in Sasak from those in Indonesian, the writer wrote them in italics. Finally, he classified the collected data based on the types of code switching of Poplack's work: inter-sentential switching, tag-switching, and intra-sentential switching and then he analyzed them to know if they were the topic switch, affective or repetitive in functions.

As described before, topic switch, affective and repetitive functions in code switching were addressed to classify teachers' use of code switching in the classroom. However, asthe Islamic preachers are like teachers who deliver their speeches and try to make the audience understand their speeches more easily by altering or switching the codes from one languages to another, those three functions of code switching might be appropriately applied to analyze the data of this study.

\section{Findings}

As stated earlier, the obtained data would be classified basedon the different types of switching provided by Poplack, viz: inter-sentential, tag, and intra-sentential switching. Therefore, in this part, the data will be presented in the order of those three types of switching followed by the analysis of function for each.

\section{Inter-sentential switching}

Inter-sentential switching takes place between sentences, and this type of switching can be found in $T G B$ 's Islamic speech. There are some examples of this type of code switching in $T G B$ 's Islamicspeech as presented in the excerpts below:

Kalau dulu, apa nenek moyang bahasa Sasak, papuk balok. Kalau dulu papuk balok pelungguh tidak bergerak, ndek ne nguit lengan balene, ndek arak side tene nengke. 
(If formerly your ancestors did not move or emigrate, you would not be here now)

Dendek te mele kalah isik matahari, yg disampaikan oleh Allah SWT dalam surat Yasin.

(We should be superior to the sun in movement and neverstop, in which the sun always rotates, likes what Allah tells in Qur'an surah Yaasin)

Ndek ne wah prei matahari terbit setiap pagi dari ufuk timur

(The sun never stops rising in the east)

Orang yg tidak mau bergerak, tidak mau berusaha, maka lambat laun hatinya akan keras, jeri tegel aten ne.

(People who do not want to move and do not endeavor to earn their livings, graduallytheir hearts will be hard)

Jeri lamun te begawaian, selain te mauk kepeng, mun te pasang niat sik bagus, niat mencari rizki yg halal, maka kerja kita itu menjadi sebab dose kita digugurkan oleh Allah. Cobak apalagai yang kurang kasih sayang Allah lek ite?

(So, if we work and intend to seek for the legal bounty, we will not only get things we want such as money, but our sins will be forgiven by Allah. Thus, don't you realize that Allah is the Merciful, the Compassionate?)

Milu-miluan Pir'aun sik pagah nyebrang, Allah mengilhamkan kepada laut untuk kembali menyatu.

(As Pharaoh, a stubborn person, and his soldiers followed Moses crossing the sea, Allah orderedthe sea to cover the drowned Pharoah and his soldiers)

Kalau urusan dunia, jangan kita lihat orang yang lebih kaya dari kita saja, mun te gitak dengan sak lebih doang lekan ite, ngonek-ngonek talon ate ite.

(For the worldliness matters, do not look at the people who are richer than us, since if we do this, we will become jealous)

Pernah gagal ibu ibu? Misalne side mele sesuatu terus sulun sulun ndek de mauk, wah ato ndek? Ndek narak manusia yang selalu berhasil.

(Have you ever failed? For instance, when you wanted to get something, but unfortunately you failed to have it, haven't you? There is no one who is free from failure)

Mari kita banyak-banyak bersilatur rahim. Mun te bedait bareng dengan lik rurung, ucapang 'salam,' bapak-bapak nggih? 
(Let's have close and good relationships with others. If we meet our brothers or sisters in Islam, say 'Salam,' ok?)

From the excerpts presented above, it is found that inter-sentential switching involves intra-sentential switching in some cases. Most of them were repetitive in functions which were intended to emphasize the important point which the audience needs to know and to clarify the meanings inwhich they would be more effective if they were delivered in Sasak instead of Indonesian languagedue to a native language for the majority of the audienceis Sasak language. In some cases, the switching from Indonesian to Sasak in $T G B$ 's Islamic speech might mean to build a solidariy and close relationship with the audience whose native language is Sasak language.

\section{Tag switching}

Tag-switching requires only little integration of the two languages, and it involves inserting a tag in one language with another language. This type of tagswitching can also be found in the Islamic speech of $T G B$, but it occurs only in some utterances in the form of questions which function as confirming and/or showing a close or friendly relationship, such as in the following excerpts.

Dari mana lagi semeton jari? Selong? Dendek sebut Selong. Selong, Pancor dendek sebut, sejau'an maeh, mana?

(Where are you from? Selong? Do not mention Selong or Pancor. Is there anyone who comesfarther than them, where?)

Berikhtiar di dunia, nggih? Bekerja, nggih?

(Please, work hard in this world, ok?)

Mudah-mudahan kalau ada rizki yang sampai, rizki yg sampai itu menjadi rizki yg barokah, nggih?

(Hopefully, the bounty or prosperity we get is that which is blessed by God Allah the almighty, ok?

\section{Intra-sentential switching}

Intra-sentential switching occurs within a sentence. As two languages are mixed within a sentence, and words or phrases from another language are inserted into the first language within one sentence or utterance, intra-sentential switching is also called code mixing. Intra-sentential switching was found to be the most frequently used in $T G B$ 's Islamic speech.

Further, it is found that most of the utterances for intra-sentential switching are repetitive in functions which might beintended to explain the Indonesian equivalent 
of word, phrases, or clauses to Sasak. The examples of this type of code switchingare presented in the excerptsbelow:

Siapa saja kata Nabi, sei-sei kalau bahasa Sasak, mau, mele, melet, dilapangkan rizkinya oleh Allah, banyak-banyak bersilaturrahim.

(Whoever wants Allah provides him or her the bounty in abundance, he/she ought to keep a good relationship with others)

Dan matahari itu jalan, lekak, berputar kata Allah, terus-menerus, tidak pernah ada kata mentelah

(Allah says that the sun rotates continuously, and never stops)

Secara mutlak tidak bisa milih, ndek ne bau milen, ndek bau Matahari, tidak bisa matahari itu mengatakan, 'ooo saya hari ini mau mentelah,' ndek ne bau.

(It is inevitable that the sun can not decide itself to stop rotating or say "I want to stop rotating, I'll take a rest today")

Itu sebabnya nabi kita, nabi besar Muhammad SAW santer isik ne ndek demen, Nabi SAW tidak suka kepada hambaNya yg diberikan kekuatan oleh Allah untuk berikhtiar tetapi tidak mau berusaha.

(That's why our prophet Muhammad peace be upon him hates people who are blessed with power, but they do not take advantage of it to earn their livings)

Cobak apalagi yang kurang kasih sayang Allah lek ite?

(Thus, don't you realize that Allah is the Merciful, the Compassionate?)

Perbaharuilah, peririlah kehidupan mu, perbaiki kehidupan kita.

(Change and make your lives better)

\section{Discussion}

The findings of this study show that TGBfrequently employed codeswitching when delivering the Islamic speech to the audience. He mostly switched the codes from Indonesia to Sasak, and in some instances he switched the codes from Sasak to Indonesia as if he is not soconfident as a user of Sasak and this case can be tracked down in utterances in which he resorted to Indonesian language after speaking or delivering utterances in Sasak language, for instance when clarifying what he meant like in the excerpt below:

Jeri mun te gitak dengan sik lebih bajang lekan ite, te sayang, te kangen, nggih? dendek te apa namanya? dendek te epe bahesene? diejek. 
(Thus, we should care and love who are younger than us, ok? Do not mock them)

This fact is in line with the theory stating that a bilingual or multilingual person does not know all the languages equally well, but he/she has a better knowledge of one language than another (Richards and Schmidt, 2002:51). Thus, when a bilingual or multilingual finds difficulty in delivering what he/she means in a language, he/she begins to switch the codes and uses another language that can facilitate him/her in delivering the intended point.

However, that $T G B$ employed code switching was not solely due to his lack of vocabulary in Sasak to convey what he meant, since he might also employ code switching when, for instance, he wanted to attract the audience's attention. This happens, for example, when he wanted to know the further place where the audience was from, like in the excerptbelow:

Dari mana lagi semeton jari? Selong? Dendek sebut Selong. Selong, Pancor dendek sebut, sejau'an maeh, mana?

(Where are you from? Selong? Do not mention Selong or Pancor. Is there anyone who comesfartherthan them? Where?

On the other hand, sometimes when $T G B$ switched the codes from Indonesia to Sasak, his reason might be to make sure everyone understood what he was delivering or explaining to them. This might be inferred asa brilliant strategy of TGBto check that everyone understoodwhat he meant andthis also might be his best strategy to emphasize the meaning or point in his speech. This is understandable since Tuang Gurufor Sasak people is like a teacher whose duty is to teach the pupils and the main or the most important purpose of teaching is to make sure that everyoneunderstands what he/she ought to understand.

Furthermore, as the audience and TGBhave command of Sasaklanguage as their mother tongue and Indonesian language as a national language, it is accepted that both languages were employed by $T G B$ when delivering his Islamic speech. Besides, that TGBdid code switching might reflect that switching to Sasak could have a powerful effect, for instance, when he suggestedthe audience for not doing bad thingsor transgressing the rules of the Islamic religion.

\section{Conclusion}

Sasak people can be categorized into the bilingual community as they have at least two languages - Sasak language as their mother tongue and the Indonesian language as the national language. When delivering the Islamic speeches to Sasak community, $T G B$ as an Islamic preacheroften switches the codesfrom Indonesian to Sasak and 
vice verse in order to get his messages across to the audience or to make his Islamic speeches more comprehensible.

In this study, 'code alternation' covers both 'code switching' and 'code mixing.' However, 'code switching' is used as a cover term including 'code mixing'since in 'code switching' type, i.e., intra-sentential switchingcan be referred to as'code mixing.'

It is found that in $T G B$ 's Islamic speech, intra-sentential switching wasthe most frequently used, in which itreflects repetitive function. The fact that $T G B$ switched codes from Indonesian to Sasak repetitively was to clarify meaning and in this way, switching from one language to another has proved to be an effective means of helping interlocutor or audience (in the context of this study)in understanding the messages. Besides, that TGBdid code switching when delivering his speech might indicate his best strategy to build solidarity and make a close or friendly relationship with the audience.

To sum up, code alternation referring tocode switching and code mixing is a representation of bilingualismor multilingualism. Besides, code alternation indicates to be an important strategy to make communication more effective among people who share or speak the same languages. 


\section{References}

Cook, Vivian. (2008). Second Language Learning and Language Teaching. Fourth Edition.London: Hodder Education.

Claros, M. S. C. \& Isharyanti, N. (2009). Code Switching and Code Mixing in Internet Chatting: between 'yes,' 'ya,' and 'si' A Case Study. The JALT CALL Journal, 5, (3), 67-78.

Gumperz, J. J. (1982). Discourse Strategies. Cambridge: Cambridge University Press.

Kamwangamalu, N.M. (2010). Multilingualism and Codeswitching in Education. In Nancy H. Hornberger \& Sandra Lee McKay (eds.) Sociolinguistics and Language Education. Toronto: Multilingual Matters

Meyerhoff, M. (2006). Introducing Sociolinguistics. New York: Routledge

Muysken, P. (2000). Bilingual speech: A Typology of Code Mixing. Cambridge: Cambridge University Press.

Poplack, Shana. (1980). Sometimes I'll Start a Sentence in Spanish Y TERMINO EN ESPANOL: Toward a Typology of Code-switching. Linguistics, 18, 581- 618.

Ricahrds, Jack C. \& Schmidt, Richard. (2002). Longmen Dictionary of Language Teaching \& Applied Linguistics, Third Edition, London: Pearson Education Limited

Romaine, S. (1995). Bilingualism. Oxford: Blackwell Publishing.

Snape, D. \& Spencer, L. (2003). The Foundations of Qualitative Research. In J. Ritchie\& J. Lewis (eds.). Qualitative Research Practice. A Guide for Social Science Students and Researchers. London: SAGE Publications

Wardhaugh, R. (2006). An Introduction to Sociolinguistics. Fifth Edition. Massachusetts: Blackwell Publishing

Wei, L. (1999). The 'why' and 'how' Questions in the Analysis of Conversational Code Switching. In P. Auer (ed.), Code Switching in Conversation: Language, Interaction and Identity. London: Routledge 
Wei, L. (2008). Research Perspectives on Bilingualism and Multilingualism. In Li Wei and Melissa G. Moyer (eds.)The Blackwell Guide to Research Methods in Billingualism and Multilingualism.Massachusetts: Blackwell Publishing. 